\title{
DAMPAK PERMASALAHAN HIDUP EMPAT TOKOH UTAMA TERHADAP KEPRIBADIAN DALAM NOVEL AUTO KARYA NATSUO KIRINO
}

\author{
Nur Hastuti \\ Fakultas Ilmu Budaya Universitas Diponegoro \\ Email : nuha_chan@yahoo.com
}

\begin{abstract}
This ressearch has title" The Impact of The Fourth Main Characters' Life Problem Toward Their Characteristic In The Novel Auto By Natsuo Kirino”. The objects ressearch is novel Auto by Natsuo Kirino that was published in 1997. This ressearch has aim to get the description of characteristic structure of the four main characters that includes id, ego, and superego, and also about what are the effects of life problem toward their characteristics. The theoritical approach that is used in this ressearch is to answer those both problems and uses Sigmund Freud's Psychoanalisist.

From the characteristics ressearch result of the four main characters, they are Masako, Yayoi, Yoshie, and Kuniko, it is proved that their characteristics are more dominated by id impuls than ego impuls or superego. This is because work characteristic of id is pleasure principle to reduce tension or problem.

The impact of life problem toward the characteristic of four main characters is descibed below. Masako has problem when she is never respected in her workplace. Difficult communication with her husband and her household that is not harmonious and her relationship with her children is not getting well. Those problems effect she does main action to reduce her tension in her life. She also helps her friend, Yayoi by throwing away Yayoi's husband corpse that had been mutilated. Yayoi has problem with her husband who never respects her and her household that is not harmonious. Solution that is done by Yayoi because of household problem is by doing main action by killing her husband. Another character, Yoshie has a problem where she must nurse her mother in law who always grumble and gets angry to her when she come late. She must also work in the night to earn money to fulfill her needs. Those facts cause fury to Yoshie, so that she wants to kill her mother in law. Yoshie wants to leave out all her burdens and tensions by helps Masako to throw away Kenji's corpse (Yayoi's husband). Another character, Kuniko has problem about she feel that she has no face beauty and perfect body shape, so that she lives in luxurious way and has many debts to the creditors to cover her lack. She does this way to reduce her tension in her life.
\end{abstract}

Keywords: novel, main character, life problem, psychoanalisist

\section{A. PENDAHULUAN}

Karya sastra khususnya novel diciptakan oleh pengarang dengan tujuan untuk dinikmati, dipahami, dan dimanfaatkan tanpa melupakan bahwa karya sastra sebenarnya merupakan bagian pengungkapan masalah hidup, filsafat dan ilmu jiwa ( Darma, 1983:52).

Gejala-gejala kejiwaan yang dapat ditangkap oleh sang pengarang dari manusia-manusia tersebut, kemudian diolah dalam batinnya dipadukan dengan kejiwaannya sendiri menjadi pengetahuan baru yang diendapkan dalam batin. Jika endapan batin sang pengarang sudah kuat, maka akan memberikan dorongan pada pengarang untuk melakukan proses kreatif menjadi sebuah karya sastra yang diciptakannya, yang terproyeksi melalui ciriciri kejiwaan para tokoh imajinernya. Sastra sebagai gejala kejiwaan terkandung fenomena-fenomena kejiwaan yang tampak melalui karakter tokoh-tokohnya. Dengan 
demikian, karya sastra dapat didekati dengan menggunakan pendekatan psikologi (Endraswara, 2008: 86-87).

Menurut Kenneth, Clark dan George Millter (dalam Supardan, 2008: 425), mendefinisikan psikologi sebagai studi ilmiah mengenai perilaku. Ruang lingkupnya mencakup berbagai proses perilaku yang dapat diamati, seperti gerak tangan, cara berbicara, perubahan kejiwaan, dan proses yang dapat diartikan sebagai pikiran dan mimpi. Psikologi memandang perilaku manusia (human behavior) sebagai reaksi yang dapat bersifat sederhana maupun bersifat kompleks.

Perilaku seseorang juga dipengaruhi dan ditentukan oleh akal dan jiwanya. Susunan unsur-unsur akal dan jiwa yang menentukan tingkah laku atau tindakan dari setiap individu manusia yang disebut dengan kepribadian (Siswanto, 2008:12). Jika seseorang hidup dalam suatu lingkungan, dimana dia tidak dapat mengatasi masalah yang melanda hidupnya, biasanya hal tersebut akan mempengaruhi kondisi kejiwaan maupun kepribadiannya. Apabila tingkat permasalahan yang terjadi pada seseorang itu berat, sehingga dia tidak dapat menahan beban masalah yang dipikulnya, biasanya dia akan melakukan hal-hal diluar kewajaran jika dalam keadaan terdesak seperti melakukan tindakan kejahatan. Adapun contoh tindakan kejahatan akibat mereka tidak dapat mengatasi masalah dalam kehidupannya tersebut, dikisahkan dalam novel Auto (Bebas) karya Natsuo Kirino di bawah ini.

Novel ini mengisahkan tentang kehidupan empat wanita tokoh utama yaitu: Masako Katori, Yayoi Yamamoto, Yoshie Azuma, dan Kuniko Jonouchi. Mereka adalah karyawan pabrik yang bertugas mengemas makanan dalam kardus, yang bekerja pada malam hari saat pergantian shift malam tiba. Mereka mempunyai masalah yang berhubungan dengan rumah tangga dan kehidupan pribadi. Mereka sendiri tidak tahu solusinya, tetapi mereka melakukan tindakan keji untuk meredakan ketegangan dari masalah yang melanda hidupnya. Permasalahan dalam kehidupan empat tokoh utama yang berdampak pada kehidupan pribadinya adalah sebagai berikut:

Masako, hidup bersama suami dan seorang putranya dengan materi berkecukupan, tetapi mereka tidak layak disebut keluarga karena masing-masing anggota keluarga bersikap masa bodoh tanpa mau memperdulikan satu dengan yang lain. Masalah lainnya adalah dia memiliki pengalaman yang buruk sebelum bekerja di pabrik makanan, yaitu dia tidak pernah naik jabatan dan tidak pernah mendapatkan penghargaan meskipun dia telah mengabdi selama 22 tahun sebagai karyawan di perusahaan pengkreditan. Justru dia selalu ditempatkan dibelakang layar bahkan di dapur untuk melayani para tamu jika ada pesta tahun baru atau pesta bulanan di perusahaan. Semua rekan prianya yang masuk kerja seangkatan dengannya sudah naik jabatan. Jabatan paling bawah malahan menjadi kepala bagian, sedangkan pegawai pria yang lebih muda darinya sudah naik pangkat dan membawahinya.

Yoshie, seorang wanita paruh baya yang hidup bersama dengan putrinya beserta mertuanya yang lumpuh, sakit-sakitan, dan suka mengeluh. Mertuanya selalu memarahinya jika dia terlambat pulang dari tempat kerja. Suami Yoshie sudah meninggal, sehingga dia harus bekerja untuk memenuhi kebutuhan finansial keluarganya. Putrinya yang diharapkan dapat membantu merawat neneknya dan mencari uang dengan kerja part-time, malahan bersikap sebaliknya. Putri Yoshie adalah siswa SMU yang lebih suka menghamburhamburkan uang hasil kerja part timenya daripada membantu finansial ibunya. Putrinya juga tidak mau membantu merawat neneknya ketika Yoshie kerja malam, bahkan putrinya sering berbohong untuk mendapatkan uang lebih darinya. Karena hal itu, Yoshie harus susah payah mencari pinjaman uang dari temannya untuk memenuhi keinginan anaknya.

Kuniko, adalah seorang wanita muda bertubuh gemuk yang mempunyai wajah tidak cantik yang bermimpi jadi orang kaya. Dia lebih suka menghambur-hamburkan uang untuk membeli pakaian dan barangbarang bermerek untuk mempercantik diri, 
daripada mengurus suami dan rumah tangganya. Akibat hal itu, dia terjerat hutang dalam jumlah besar. Akibat dari masalah yang ditimbulkannya itu, dia dikejar rentenir untuk melunasi hutangnya dan ditinggal pergi suaminya.

Sementara Yayoi, hidup bersama dengan suami yang senang berjudi, main perempuan, dan sering memukulnya karena masalah finansial. Padahal mereka telah memiliki dua orang anak yang masih balita. Karena sudah tidak tahan lagi dengan tingkah laku suaminya ( Kenji Yamamoto), akhirnya Yoshie membunuhnya. Sebelum dibunuh istrinya, Kenji Yamamoto terlibat perkelahian dengan seorang pemilik klub bernama Satake. Dikarenakan Kenji sering mengganggu pegawai Satake yang bernama Anna Rie. Selain itu juga, dia (Kenji) sering berhutang ketika berjudi di klubnya (Satake). Yayoi yang sudah sudah geram dengan tingkah laku suaminya, akhirnya dia membunuhnya. Yayoi yang kebingungan akibat perbuatannya itu, meminta tolong kepada para sahabatnya (Masako, Yoshie, dan Kuniko) untuk menolong menyingkirkan mayat suaminya (Kenji Yamamoto). Mereka (para sahabat Yayoi) memutuskan bahwa mayat Kenji harus dimutilasi dan dibuang di tempat terpisah.

Masalah kemudian muncul saat polisi menemukan potongan mayat Kenji di tong sampah di dalam taman. Ditambah lagi Satake yang dipenjara karena dituduh sebagai pembunuh Kenji oleh polisi. Satake bermaksud membalas dendam terhadap Yayoi dan para sahabatnya. Akibat dari perbuatan mereka, dia telah kehilangan segala miliknya. Masa lalunya yang kelam juga telah diketahui oleh orang-orang di sekelilingnya. Masalah menjadi semakin rumit, saat Kuniko membocorkan rahasia mereka kepada rentenir agar dia terbebas dari jeratan hutang.

Sesungguhnya kehidupan empat tokoh utama ini sebelum pembunuhan Kenji adalah kehidupan yang banyak dipenuhi oleh permasalahan hidup yang berdampak pada keputusasaan, serta tidak ada kebahagiaan. Mereka mengira, bahwa pembunuhan dan upaya mehilangkan mayat Kenji akan memberikan mereka kebebasan dari permasalahan, serta situasi yang memasung dalam kehidupan mereka itu. Masako dari kehidupan keluarganya yang terkucil dan kehidupan masa lalunya, Yayoi dari kekerasan domestik rumah tangganya, Yayoi dan Kuniko dari jeratan finansial keluarganya.

Berdasarkan latar belakang di atas, untuk mengetahui secara mendalam kepribadian empat tokoh utama dibutuhkan ilmu bantu untuk mengupasnya, yaitu pendekatan psikologi, tepatnya pendekatan psikoanalisis Sigmund Freud. Menurut Suroso, dkk ( 2009: 41), Psikoanalisis adalah wilayah kajian psikologi sastra yang menganalisis secara terperinci pengalaman emosional yang dapat menjadi sumber atau sebab gangguan jiwa tokohnya. Selain kepribadian yang meliputi id, ego, superego, lalu apa saja pengaruh permasalahan dalam hidup empat tokoh utama terhadap kepribadiannya. Hal ini sangat menarik untuk diteliti melalui novel Auto karya Natsuo Kirino.

\section{B. RUMUSAN MASALAH}

Berdasarkan uraian di atas, permasalahan yang penulis bahas dalam penelitian ini adalah:

1. Bagaimana struktur kepribadian empat tokoh utama yang meliputi id, ego, superego dalam novel Auto.

2. Apa saja pengaruh permasalahan hidup empat tokoh utama terhadap kepribadian mereka dalam novel Auto.

\section{TUJUAN PENULISAN}

Berdasarkan latar belakang dan perumusan masalah di atas, tujuan penelitian ini adalah sebagai berikut:

1. Mengungkapkan struktur kepribadian empat tokoh utama yang meliputi id, ego, superego dalam novel Auto.

2. Mengungkapkan pengaruh permasalahan hidup empat tokoh utama terhadap kepribadian mereka dalam novel Auto. 


\section{LANDASAN TEORI}

Penelitian terhadap novel Auto menggunakan teori psikoanalisis Freud. Menurut Schellenberg (melalui Ratna, 2004: 62), semua gejala yang bersifat mental bersifat tak sadar yang tertutup oleh alam kesadaran. Teori kepribadian menurut Freud dibagi menjadi tiga, yaitu: a) $I d$ atau $E s$, b) Ego atau Ich, dan c) Superego atau Uber Ich.

\section{Teori Psikoanalisis}

Freud berpendapat dalam bahwa tingkah laku manusia merupakan produk interaksi dari ketiga sistem, yaitu : id, ego dan superego. Artinya, bahwa setiap tingkah laku itu ada unsur nafsu (dorongan), unsur kesadaran nyata dan unsur pengendalian : terlepas benar atau salah, baik atau buruk (Fudyartanta, 2006:102).

Berikut adalah penjelasan tentang ketiga sistem tersebut yang penulis ringkas dari buku Theories of Personality karya Jess Feist, Teori Kepribadian Terapi Psikoanalitik Freud karya Yustinus Semiun, Metode Penelitian Sastra: Analisis Psikologis karya Siswantoro, dan Kritik Sastra: Teori, Metodologi, dan Aplikasi karya Suroso,dkk.

\section{Id}

Di inti kepribadian dan sungguhsungguh tidak disadar atau berada di alam bawah sadar adalah wilayah psikis yang disebut id. ld merupakan bagian yang paling primitif dalam kepribadian. ld merupakan sumber energi utama yang memungkinkan manusia untuk bertahan hidup. Dari Id inilah nanti ego dan superego berkembang.ld terdiri dari dorongan-dorongan biologis dasar seperti kebutuhan untuk makan, minum, buang air besar, menghindari rasa sakit, dan memperoleh kenikmatan seksual. Freud juga beranggapan bahwa agresivitas merupakan suatu dorongan biologis, oleh karena itu ada dalam id. Freud beranggapan bahwa dalam id terdapat dua jenis energi yang bertentangan yaitu insting kehidupan dan insting kematian. lnsting kehidupan ini disebut libido. Kedua macam insting ini sangat mempengaruhi kehidupan individu. Dorongan-dorongan dalam ld selalu ingin segera dipuaskan, dan dalam pemuasannya ld selalu berusaha untuk menghindari pengalaman-pengalaman yang tidak menyenangkan. Cara pemuasan dorongan seperti ini disebut menuruti suatu prinsip kesenangan. Ada dua cara pemuasan.Pertama, pemuasan dilakukan lewat refleks-refleks yang memang sudah ada sejak anak dilahirkan (misalnya: refleks menghisap). Melalui refleks-refleks ini ketegangan yang timbul karena munculnuya dorongan atau kebutuhan dapat diturunkan (dikurangi).

Kedua, dengan cara menyajikan gambaran mental tentang objek yang diinginkan. Ini disebut proses primer, dan pengalaman yang diperoleh disebut wishfulfillment (pemenuhan harapan).

Id tidak memiliki kontak dengan realitas, dia tidak bisa diubah entah oleh perjalanan waktu atau oleh pengalamanpengalaman pribadinya, namun dia terus berjuang untuk mereduksi ketegangan melalui hasrat-hasrat dasar menyenangkan. Menurut Semiun ( 2006: 61), id tidak bisa menanggulangi peningkatan energi yang dialaminya sebagai keadaan-keadaan tegangan yang tidak menyenangkan. Karena itu, apabila tingkat organisme meningkatentah sebagai akibat stimulasi dari luar atau rangsangan-rangsangan yang timbul dari dalam-maka id akan bekerja sedemikian rupa untuk segera menghentikan tegangan dan mengembalikan organisme pada tingkat energi yang rendah serta menyenangkan. Prinsip yang merupakan reduksi tegangan yang merupakan ciri kerja id ini disebut prinsip kenikmatan (Pleasure Principle).

Selain tidak realistis dan hanya mencari kesenangan, id juga tidak logis dan dapat melayani secara bersamaan ide-ide yang tidak bersesuaian. Contohnya, seorang perempuan mungkin menunjukan rasa kasih sayang yang disadari terhadap ibunya sementara mengharapkan tanpa sadar kehancuran sang ibu. Hastrat-hasrat yang saling bertentangan ini dapat muncul karena id tidak memiliki moralitas di dalamnya, artinya dia tidak membuat penentuan nilai atau membedakan baik dan buruk. Namun begitu, id bukannya immoral (menyalahi moral), tepatnya dia amoral. Semua energi id dihabiskan untuk satu tujuan saja-mencari 
kesenangan tanpa peduli apa yang pantas atau benar (Freud dalam Feist, 2008: 27).

Sebagaimana yang dijelaskan

Siswantoro (2005: 38-39), bahwa Id merupakan watak dasar manusia yang hadir sejak manusia lahir dan berisi sifat-sifat keturunan, naluri seksual dan agresif. Ciriciri watak primitif kepribadian ini adalah: kasar, beringas, kebinatangan, tidak mau diatur, tidak taat norma, dan hukum. Bertolak dari watak primitif yang demikian, wajar kalau id tidak terikat oleh larangan serta aturan yang berlaku di masyarakat. Id cenderung menghendaki penyaluran atau pelampiasan untuk setiap keinginan, yang jikalau tertahan atau tersumbat, akan mengalami ketegangan.

Singkatnya id adalah sesuatu yang primitif/ purba, khaos dan tidak terakses bagi alam sadar, tidak dapat diubah, amoral, tidak logis, tidak terorganisasikan, dan selalu dipenuhi oleh energi yang diterimanya dari dorongan dasar menuju pemuasan prinsip kesenangan. Menurut Semiun ( 2006: 62), bahwa untuk menjalankan fungsinya Id memiliki dua mekanisme dasar, yaitu: tindakan-tindakan refleks dan proses primer. Proses pertama adalah tindakan-tindakan refleks, yaitu tindakan-tindakan yang mekanisme kerjanya otomatis dan bawaan, seperti bersin, berkedip, kemudian bayi dalam keadaan lapar biasanya mulut bayi akan langsung mengatup pada puting susu ibunya dan menghisap susu. Tindakan-tindakan itu biasanya segera mereduksikan ketegangan.

Proses kedua adalah proses primer, proses dimana manusia membayangkan atau mengkhayalkan sesuatu yang dapat mengurangi atau menghilangkan tegangan, dipakai untuk menangani stimulus kompleks yang memiliki ciri: tidak logis, tidak rasional, tidak dapat membedakan khayalan dan realitas, tidak dapat membedakan antara saya dan bukan saya. Seperti bayi yang lapar membayangkan makanan atau puting ibunya. Untuk dapat bertahan hidup seorang bayi mutlak harus dapat membedakan mana yang khayal mana yang kenyataan. Dengan demikian, individu membutuhkan sistem lain yang bisa mengarahkannya kepada pengurangan tegangan secara nyata, yang bisa memberi kepuasan tanpa menimbulkan ketegangan, mampu berpikir secara rasional dalam mencari pemecahan masalah yang terbaik. Sistem yang dibutuhkan itu tidak lain adalah ego.

\section{Ego}

Ego adalah bagian "eksekutif' dari kepribadian. la berfungsi secara logis/rasional berdasarkan prinsip kenyataan (reality principle) dan proses sekunder yaitu suatu proses log is untuk melihat pada kenyataan (reality testing) dalam usahanya memenuhi cara pemuasan dorongan Id secara realistis. Fungsi Ego ini berguna untuk menyaring dorongan-dorongan yang ingin dipuaskan oleh Id berdasarkan kenyataan.

Ego adalah segi kepribadian yang dapat membedakan antara khayalan dan kenyataan. Ego juga merupakan satusatunya wilayah jiwa yang berhubungan dengan realitas, artinya ia dapat menunda pemuasan diri atau mencari bentuk pemuasan lain yang lebih sesuai dengan batas lingkungan (fisik maupun sosial) dan hati nurani. Sebagai satu-satunya wilayah jiwa yang berhubungan dengan dunia eksternal, ego menjadi pembuat keputusankeputusan atau cabang eksekutif dari kepribadia manusia. Karena dia memiliki komponen alam sadar, ambang kesadaran dan alam bawah sadar. Ego dapat membuat keputusan bagi tiap-tiap tingkatan mental ini.

Menurut Freud dalam Semiun (2006:64), ego dikatakan mengikuti prinsip kenyataan (reality principle) dan beroperasi menurut proses sekunder. Tujuan prinsip kenyataan adalah mencegah terjadinya tegangan sampai ditemukan suatu objek yang cocok untuk pemuasan kebutuhan. Jika prinsip kesenangan akhirnya terpenuhi ketika objek yang dibutuhkan ditemukan dan dengan demikian tegangan direduksikan. Proses sekunder menunjuk ego menyusun rencana memuaskan kebutuhan dan kemudian menguji rencana ini, biasanya melalui suatu tindakan untuk melihat apakah rencana itu berhasil atau tidak. Perbedaan pokok antara id dan ego adalah bahwa id hanya mengenal kenyataan 
subjektif jiwa, sedangkan ego membedakan antara hal-hal yang terdapat dalam batin dan hal-hal yang terdapat dalam dunia luar. Suroso,dkk (2009: 42), mengatakan ego biasanya mengawal dan menekan dorongan id, mengubah sifat id yang abstrak ke halhal yang berdasarkan pada prinsip kenyataan.

\section{Super Ego}

Super ego adalah gambaran intemalisasi nilai dan moral masyarakat yang diajarkan orang tua dan orang lain pada anak. Pada dasamya super ego merupakan hati nurani (concience) seseorang. Superego menilai apakah suatu tindakan itu benar atau salah. Super ego mewakili nilai-nilai ideal. Oleh karena itu superego selalu berorientasi pada kesempumaan. Cita-cita diri- nyapun diarahkan pada nilai-nilai ideal itu sehingga setiap orang memiliki suatu gambaran ten tang dirinya yang paling ideal (Ego ideal). Hadiah atau hukuman yang diterima sehubungan dengan nilai-nilai ideal itu akan membentuk dalam dirinya suara hati (concience). Bersama-sama dengan ego, superego mengatur dan mengarahkan tingkah laku manusia yang bermaksud memuaskan dorongan-dorongan dari Id, yaitu melalui aturan-aturan dalam masyarakat, agama, atau keyakinankeyakinan tertentu mengenai perilaku yang baik dan buruk.

Menurut Freud (melalui Feist, 2008: 28), superego yang berkembang dengan baik bertindak untuk mengontrol impuls-impuls seksual dan agresif lewat prosesi represi. Dia tidak dapat menghasilkan represi dari dirinya sendiri namun, dia dapat memberikan perintah agar ego melakukannya. Superego mengawasi ego dari dekat, menilai tindakan-tindakan dan niat-niatnya. Rasa bersalah (superego) adalah hasilnya ketika ego melakukan tindakan-atau bahkan baru berniat. Sedangkan perasaan rendah diri muncul ketika ego tidak mampu memenuhi standar kesempurnaan superego. Hal ini berarti rasa bersalah adalah fungsi dari suara hati nurani.

Berbeda dengan ego yang berpegang pada prinsip realitas, superego yang memungkinkan manusia memiliki pengendalian diri (self control) selalu akan menuntut kesempurnaan manusia dalam pikiran, perkataan dan perbuatan. Hal ini menunjukan bahwa superego (penuntun moral dan aspirasi seseorang) berfungsi sebagai lapisan yang menolak sesuatu yang melanggar prinsip moral. Jadi, superego mengontrol dorongan-dorongan kebutuhan id, dan berisi nilai-nilai atau evaluatif.

\section{E. PEMBAHASAN}

\section{Karakter Tokoh Utama}

Membaca sebuah novel, biasanya, kita akan dihadapkan pada sejumlah tokoh yang hadir di dalamnya, salah satu contohnya adalah tokoh utama. Sebagaimana yang dijelaskan Nurgiyantoro (2005: 176-177), yang disebut tokoh utama adalah tokoh yang diutamakan penceritaannya dalam novel yang bersangkutan. Ia merupakan tokoh yang paling banyak diceritakan, baik sebagai pelaku kejadian maupun dikenai kejadian. Bahkan pada novel-novel tertentu, tokoh utama senantiasa hadir dalam tiap halaman buku cerita yang bersangkutan. Tokoh utama dalam sebuah novel, mungkin saja lebih dari seorang, walau kadar keutamaannya tidak sama. Keutamaan mereka ditentukan oleh dominasi, banyaknya penceritaan, dan pengaruhnya terhadap perkembangan urutan kejadian secara keseluruhan.

Selain tokoh utama, di dalam sebuah novel juga ada yang namanya karakter. Menurut Stanton ( 2007: 33), karakter dipakai dalam dua konteks. Konteks yang pertama merujuk pada individu-individu yang muncul dalam cerita, dan konteks kedua merujuk pada percampuran dari berbagai kepentingan, keinginan, emosi, dan prinsip moral dari individu-individu tersebut. Ini berarti, kita dapat mengamati ciri-ciri seorang karakter, perkembangannya, sikap-sikapnya terhadap terhadap karakterkarakter lain, atau efek sikap-sikap tersebut pada mereka. Berikut adalah analisis karakter ke-4 tokoh utama dalam novel Auto. 


\section{a. Karakter Tokoh Masako}

Masako memiliki karakter suka memutuskan sesuatu secara tiba-tiba. Sifatnya itu ditunjukkan ketika tiba-tiba dia dirasuki keinginan untuk membantu Yayoi menyingkirkan mayat Kenji (suaminya), padahal dia tahu bahwa Yayoi telah membunuhnya. Dalam psikoanalisis, tindakan Masako itu didorong oleh id. Id adalah bagian dari kepribadian yang beroperasi berdasarkan kenikmatan. Id beroperasi untuk mencapai kepuasan semata tanpa mempertimbangkan baik dan buruk. Seperti dalam kutipan berikut ini.

$$
\begin{aligned}
& \text { それしか方法はないだろう。雅子は } \\
& \text { あっけなく同意した。 } \\
& \text { 「ありがとう。お礼はするから」 } \\
& \text { 「お金は要らない」 } \\
& \text { 「どうして。じゃ、どうしてここま } \\
& \text { でしてくれるの」弥生は健司の腕の } \\
& \text { 下に腕を差しいれながら、雅子に } \\
& \text { 訊ねた。「さあ、あとで考え } \\
& \text { る」雅子はかって弥生の夫だった男 } \\
& \text { の力の抜けた両足を摑んで持ち上げ } \\
& \text { た。（アウト：102） }
\end{aligned}
$$

Masako tahu mungkin memang inilah satu-satunya pilihan mereka, dan tibatiba saja dia sudah menyetujuinya.

"Aku tidak tahu bagaimana harus berterima kasih padamu, tapi aku pasti akan membalas budi. Aku bisa membayarmu,"kata Yayoi.

"Aku tidak menginginkan uangmu."

"Kenapa tidak? kenapa kau bersedia melakukan semua ini?'YYayoi terus bertanya sambil mengangkat lengan Kenji.

“Aku juga kurang tahu,"Jawab Masako sambil meraih sepasang kaki lunglai milik pria yang dulunya suami Yayoi. (Bebas, hal.82)

\section{b. Karakter Tokoh Yayoi}

Yayoi digambarkan sebagai tokoh pemicu konflik keterlibatan rekan-rekannya dalam usaha membantu menyingkirkan mayat suaminya. Yayoi mempunyai karakter tidak bertanggung jawab padahal dia telah membunuh suaminya. Dia membuat alibi dengan cara menelpon polisi dan mengatakan suaminya belum pulang.
Sebaliknya, dia memiliki hati yang sensitif. Seperti terlihat dalam kutipan berikut ini.

「実は昨夜、うちには帰って来なか ったんです。どこに泊まったのか分 りませんが、会社には出ていると思 っていたんですけど。電話して確か めるのも怒られそうだし、どうしよ うかと」

(アウト : 170)

「心配なんですよ。こんなこと初 めてだから」（アウト：176）

"Sebenarnya, suami saya tidak pulang semalam. Saya tidak tahu dia menginap di mana, tapi saya pikir dia pasti sudah di kantor sekarang. Saya tahu dia marah kalau saya menelponnya ke kantor, jadi tadi ini saya masih berpikir-pikir apa yang sebaiknya saya lakukan.” (Bebas:133)

"Aduh, saya tidak tahu harus bagaimana,"kata Yayoi."Ini belum pernah terjadi ."(Bebas, hal.138)

Dalam psikoanalisis, tindakan Yayoi berpura-pura kepada polisi dan mengatakan bahwa dia tidak tahu keberadaan suaminya padahal dia telah menghilangkan nyawa Kenji merupakan dorongan id, dimana Yayoi tidak mau hidup dengan suami yang sering memukulnya, menghabiskan uang keluarga untuk berjudi dan main perempuan.

Meskipun Yayoi mempunyai karakter tidak bertanggung jawab, Yayoi mempunyai hati yang sensitif. Ketika Kuniko datang ke rumah Yayoi dengan maksud meminta bayaran karena telah membantu membuang mayat suaminya. Kuniko mengatakan betapa mengerikan mayat suaminya dibuang dengan cara dipotong-potong. Hal tersebut membuat Yayoi tidak kuat mendengarnya dan meminta Kuniko untuk menghentikan ceritanya, karena Yayoi tidak tahan membayangkan saat suaminya dipotongpotong. Yayoi memang tidak melihat langsung saat teman-temannya melakukan semua itu. Seperti kutipan di bawah ini.

「聞きたくなくたってしょうがない じゃない。いいですか、あたしは山 本さんのご主人の肉をこうやって摘 んでゴミの袋に入れさせられたんで 
す。それがどんなに気持悪くて嫌な ことが、分ってます?え、分ってま すか」（アウト：248）

"Kau mungkin tak mau, tapi kau harus mendengarkan . Mengerti? Aku memegang potongan-potongan suamimu seperti aku memegangmu sekarang, lalu aku memasukannya ke dalam kantong sampah. Bisa kaubayangkan betapa menjijikannya itu? Bisa tidak?!" (Bebas, hal.194)

「お願い、言わないで。お願い」 (アウト : 249)

"Tolong," kata Yayoi. “ Tolong, sudah cukup.” (Bebas, hal.194)

\section{c. Karakter Tokoh Yoshie}

Di usianya yang sudah tua, karakter Yoshie digambarkan oleh Natsuo Kirino sebagai seorang wanita yang keras kepala tapi mudah dibujuk dan diancam oleh temannya (Masako) untuk membantu memotong mayat Kenji. Akhirnya, dia pun menuruti permintaan Masako. Sebenarnya dia dalam keadaan terdesak, apabila tidak membantunya maka dia harus membayar hutang yang dipinjam dari Masako. Seperti terlihat dalam kutipan di bawah ini.

「あたしは駄目。できないよ、そん なこと。絶対」

「じや、金返してよ」雅子はテーブル 越しに手を出した。「昨日貸した 八万三千円、耳を揃えて今日返して よ」（アウト：121）

"Lupakan saja,"kata Yoshie sambil menggeleng dengan keras kepala."Aku tak sanggup. Yang itu aku tak sanggup."

"Ya sudah," Tukas Masako sambil mengulurkan telapak tangannya yang terbuka ke atas meja."Kalau begitu, kembalikan uang yang kupinjamkan padamu kemarin malam. Sekarang." (Bebas, hal.97)

\section{d. Karakter Tokoh Kuniko}

Di usianya yang masih muda dan dewasa, Kuniko digambarkan oleh Natsuo Kirino sebagai seorang wanita yang memiliki karakter kasar dan ingin menang sendiri baik kepada suami maupun temannya. Seperti terlihat dalam kutipan berikut ini.

「何よ。どうせもうじき起きるんで しょうが」

「まだ十分くらい、いいんじゃ ないよ」何かが飛んできて腕に当た った。百円ライターだった。当たっ た箇所が赤くなっている。邦子は、 そのライターを摑むと、哲也の寝て いるベッドの横にぬっと立った。

「この邦子。あたしが疲れてんの がわかんねえのかよ!」

「何だよ。」目を開けた哲也の

顔に怯えが走った。「俺だって疲れ てんだよ。」

「だからってこんなもん逃げっけも いいと思ってるのか」邦子

はライターに点火し、哲也の顔の前 にかざした。（アウト：31）

"Kenapa?" tukas Kuniko." Kan memang sudah waktunya kau bangun." "Aku masih punya waktu sepuluh menit!"suaminya berteriak lagi, dan Kuniko merasakan sesuatu menghantam lengannya. Lalu dia melihat pemantik sekali pakai yang pasti baru dilempar oleh Tetsuya tergeletak di lantai. Kulit lengannya mulai memerah. Dipungutnya pemantik itu dan dia berjalan ke ranjang tempat Tetsuya masih berbaring.

"Bajingan. Aku ini setengah mati kecapekan, tahu?"

“Apa?'kata Tetsuya dengan wajah agak takut-takut." Justru aku yang kecapekan."

"Jadi, kaukira kau berhak menyambitku dengan ini?" Kuniko menyalakan pemantik itu dan mendekatkannya ke wajah Tetsuya.(Bebas, hal.26) 
Selain kasar pada suaminya, Kuniko juga kasar dan menindas kepada temannya sendiri yaitu Yayoi. Sebab, Kuniko sangat membutuhkan uang untuk membayar hutangnya kepada rentenir. Seperti terlihat dalam kutipan berikut ini.

「聞きたくなくたってしょうが

じやない。いいですか、あたしは山 本さんのご主人の肉をこうやって摘 んでゴミの袋入れさせれたんですよ。 それがどんなに気持ち悪く嫌なこと か、わかってます?え、わかってま すか小

\section{「わかってます」}

「いや、あんたはわかってない」邦

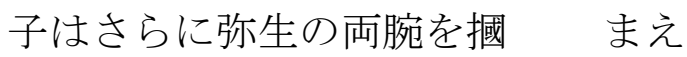

た。弥生は悲鳴を上げ、「やめてよ」 と飛んだが邦子は力を緩めなかった。 (アウト : 249)

"Kau mungkin tak mau, tapi kau harus mendengarkan. Mengerti? Aku memegang potongan-potongan suamimu seperti aku memegangmu sekarang, lalu aku memasukannya ke dalam kantong sampah. Bisa kau bayangkan betapa menjijikannya itu? Bias tidak?!"

Yayoi.

"Bisa...bisa..," guman

"Apanya!" Kuniko menjerit sambil meraih tangan Yayoi yang satu lagi.

"Hentikan!" Yayoi memohon, tapi cengkeraman Kuniko sepertinya malah makin erat. (Bebas: 194)

\section{Pengaruh Permasalahan Hidup Empat Tokoh Utama Terhadap Kepribadiannya} Berikut ini adalah pengaruh permasalahan hidup empat tokoh utama terhadap kepribadiannya dalam novel Auto karya Natsuo Kirino, yaitu sebagai berikut:

\section{a. Pengaruh Permasalahan Hidup Masako Terhadap Kepribadiannya}

Masako memiliki permasalahan hidup yang berasal dari masalah sebelum bekerja di pabrik, dimana dia tidak dihargai sama sekali sebagai pegawai senior. Kerja kerasnya selama di perusahaan selama 22 tahun pun sia-sia karena dia tidak pernah naik jabatan. Sebaliknya rekan prianya sudah naik pangkat, malahan dia di PHK dari tempatnya bekerja. Pada saat dia di PHK dan gagal mencari kerja pun, suami Masako tidak memperdulikannya.

Masalah lain yang menjadi beban hidupnya adalah masalah rumah tangganya. Hubungan komunikasi dengan suami tidak lagi harmonis, suaminya dicengkeram depresi karena pekerjaannya. Hal itu berdampak pada ketegangan hubungan dan persoalan rumah tangga Masako yang semakin buruk. Keluarganya lebih memilih menanggung beban masalah dan hidupnya masing-masing. Seperti terlihat dalam kutipan berikut ini.

しかし、新年会などは一年に一度し かないのだから気にしてはいられな いかった。何よりも雅子が憤りを感 じたのは、毎日努力しているのに、 何年経って役職にも就けないし、融 資事務という入社した時とまったく 同じ仕事をさせられていることだっ た。朝八時に早出して毎日九時近く まで残業しても、雅子の仕事の内容 は、十年一日変わらない。どんなに 仕事に励んでも、

融資決定など重要な仕事は男性社員 がやり、雅子にはその補助 の仕事しか与えられないのだ。同期 の男性社員は皆、研究を積んで十年 ほどで係長になり、雅子をどんどん 追い越していてく。後輩の男たちも いつしか自分の上司になるようにな った。（アウト：291-292）

Toh pesta itu Cuma sekali setahun dan untuk sehari itu saja dia masih bisa bersabar. Yang meresahkannya adalah usaha kerasnya selama 364 hari lainnya dalam setahun itu tak pernah memperoleh pujian, dan selama bertahun-tahun ini dia tak pernah naik pangkat atau diberi sekedar tugas administrasif sejak pertama ia bekerja disini. Walaupun dia tiba pukul 08.00 pagi dan tetap di kantor sampai pukul 21.00 hampir tiap malam, dia tetap saja melakukan pekerjaan yang sama dan membosankan tahun demi tahun; tak peduli betapa kerasnya ia berusaha, atau 
betapa bagus kinerjanya, dia hanya memainkan peran pembantu, sedangkan semua keputusan penting berada di tangan rekan-rekan prianya. Pria-pria yang masuk perusahaan itu pada waktu yang kurang lebih sama dengan Masako semuanya sudah diikutkan program pelatihan besar-besaran dan sudah lama naik pangkat, paling sedikit menjadi kepala bagian, dan sekarang bahkan pria-pria yang lebih muda darinya pun mulai naik pangkat membawahinya.

( Bebas, hal. 224)

再就職先が見つからず、とうとう弁 当工場の夜勤パートを選んだ雅子に、 良樹は何も意見を 言わなかった。

（アウト：97）

Yoshiki (suami) tidak mengatakan apaapa padanya sewaktu Masako gagal memperoleh pekerjaan lain dan akhirnya bekerja shift malam dipabrik makan siang kotakan. (Bebas, hal.78)

Permasalahan hidup ditambah saat anak yang dia banggakan menjauh dan tidak mau berbicara dengannya. Anaknya bersikap demikian semenjak dikeluarkan dari sekolah dan dituduh membawa narkoba. Akibat sikap anaknya yang diam membisu itu, suatu waktu Masako menamparnya karena anaknya tidak mau mendengarkan nasehat darinya. Seperti terlihat dalam kutipan berikut ini.

「喋りたくなきゃそれでも いいよ。でも、勝手なことしない で」伸樹は憮然として口を歪め、か ったるそうに騅子を見下ろした。息 子なのに見知らぬ地人、それも好き ではない地人のような気がして、思 わず雅子は伸樹の顇を右手で張って いた。一瞬触伸樹顇の感触は、肉が 薄くて締まり、すでに柔らかい少年 のものではなかった。打ったてのほ うが痛い。はっとして立らすくんで いると、伸樹は雅子の横を通り、素 早く洗面所に消えた。やはり一言も 発しなかった。

(アウト : 132)
"Aku tidak peduli kau mau bicara atau tidak,"kata ibunya, "tapi kau tidak boleh berbuat seperti itu."Nobuki memasang tampang kaget dan memandangnya dengan mata melompong; dan Masako berpikir betapa anaknya terasa seperti orang asing kini -orang asing yang tidak terlalu disukainya. Tanpa berpikir dia mengangkat tangan dan menampar nobuki . (....) Nobuki berdiri sebentar, terpana, lalu maju dan setelah menabrak ibunya menghilang ke dalam kamar mandi tanpa berkata sepatah kata pun. (Bebas, hal. 104)

Masako merasa bahwa usahanya untuk dapat berkomunikasi dan mendekati anaknya hanyalah impian semu dan sia-sia saja. Suaminya yang berada didekat mereka saat kejadian itu, hanya membisu dan tidak perduli dengan kondisi yang menimpa anaknya. Seperti terlihat dalam kutipan berikut ini.

$$
\begin{aligned}
& \text { 何を期待していたのか、これらの言 } \\
& \text { 動は炎天の砂漠に水を撒くように無 } \\
& \text { 䭾なことだった。 } \\
& \text { 雅子は赤くなった右にの掌を見つ } \\
& \text { め、それから良櫉を振り返。 } \\
& \text { だが、良樹は伸樹など存在していな } \\
& \text { いかのように新聞に眼を張 } \\
& \text { りつかせたままま動かない。（アウ } \\
& \text { ト:132） }
\end{aligned}
$$

Masako tidak tahu apa yang diharapkannya tadi; rasanya apapun yang dikatakannya atau dilakukannya sia-sia saja, seperti tetesan air di padang gurun yang kering kerontang. Dia memandangi telapak tangannya yang merah sejenak, lalu memandang Yoshiki; tapi suaminya itu duduk saja tak bergerak, matanya tetap terarah ke koran, seakan-akan dia tak punya anak, seakan-akan tak pernah ada anak lakilaki bernama Nobuki dalam hidupnya.( Bebas, hal. 105 )

Ketidaksenangan kondisi dalam rumah tangganya menyebabkan beban berat yang dirasakan Masako. Dia sudah mencoba mendekati anaknya, tapi selalu gagal. 
Solusi yang dilakukan Masako untuk menghilangkan ketegangan akibat permasalahan hidupnya adalah melakukan tindakan keji dengan membantu membuang mayat suami Yayoi dengan memutilasinya, seperti kutipan berikut ini:

「バラバラにして捨てるつもりです。

で、山ちゃんは知らぬ存ぜめで暮ら

す。そうすれば、亭主は行方不明、

で何かなるんだよ」。（アウト：

121)

"Aku akan memotong-motongnya, lalu membuangnya. Setelah itu Yayoi bisa kembali menjalani hidupnya seperti biasa, seakan tak pernah terjadi apa-apa. Mereka akan menganggap suaminya hilang, dan selesai sudah." (Bebas: 97)

Apa yang dilakukan Masako sebagai cara untuk mereduksi ketegangan dari masalah hidup yang dialaminya, dimana egonya menjadi pembuat keputusan melakukan tindakan tersebut. Menurut Freud melalui Semiun ( 2006:64), ego dikatakan mengikuti prinsip kenyataan (reality principle) dan beroperasi menurut proses sekunder. Tujuan prinsip kenyataan adalah mencegah terjadinya tegangan sampai ditemukan suatu objek yang cocok untuk pemuasan kebutuhan. Jika prinsip kesenangan akhirnya terpenuhi ketika objek yang dibutuhkan ditemukan dan dengan demikian tegangan direduksikan. Ini berarti bahwa untuk menghilangkan ketegangan itu, Masako telah menemukan cara dengan menjadikan mayat Kenji sebagai objek pereduksi masalah yang melanda hidupnya.

\section{b. Pengaruh Permasalahan Hidup Yayoi Terhadap Kepribadiannya}

Manusia hidup memerlukan kasih sayang untuk dicintai, dihargai, tapi hal setelah kebutuhan dicintai dan dimiliki tercukupi, manusia akan bebas untuk mengejar kebutuhan untuk dihargai, yang mencakup penghargaan-diri, keyakinan, kompetensi, dan pengetahuan bahwa orang lain memandang mereka dengan perasaan menghargai. Setelah kebutuhan dicintai dan dimiliki tercukupi, manusia akan bebas untuk mengejar kebutuhan untuk dihargai, yang mencakup penghargaan-diri, keyakinan, kompetensi, dan pengetahuan bahwa orang lain memandang mereka dengan perasaan menghargai (Maslow melalui Feist, 2008).

Tapi hal tersebut tidak didapatkan oleh Yayoi, suami yang dicintai ternyata tidak menghargainya sama sekali, uang hasil jerih payah Yayoi telah dihabiskan Kenji untuk bermain Judi, tidak ada penghargaan sama sekali terhadap istrinya. Seperti kutipan berikut ini:

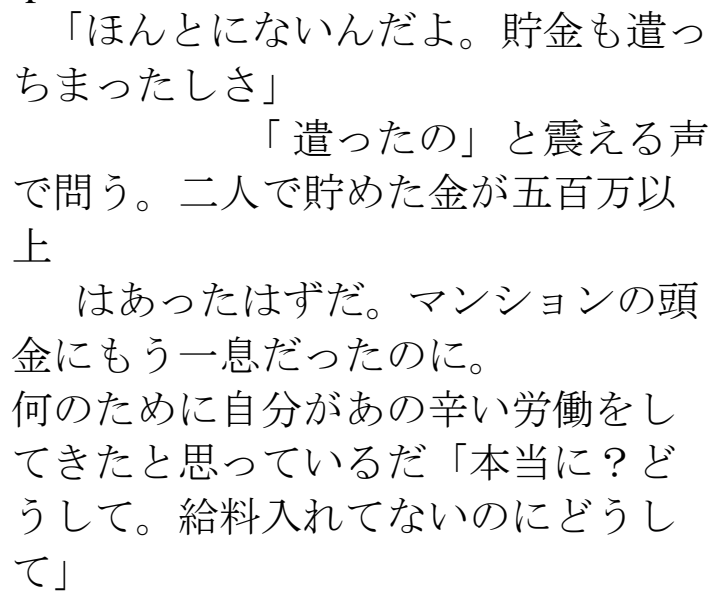

「ほんとにないんだよ。貯金も遣っ ちまったしさ」

「遣ったの」と震える声 で問う。二人で貯めた金が五百万以

はあったはずだ。マンションの頭 金にもう一息だったのに。

何のために自分があの辛い労働をし

てきたと思っているだ「本当に? ど

うして。給料入れてないのによ゙うし

$\tau\lrcorner$

上

「博打。バカラってやつ」 「嘘でしよう」呆れてそ

れしか言えなかった。

「ほっと」

$$
\begin{gathered}
\text { 「だって、あなただけの } \\
\text { ものじやないでしょう」 } \\
\text { 「おまえのもんでもない } \\
\text { だろう」（アウト：87） }
\end{gathered}
$$

"Tidak, aku betul-betul bangkrut. Dan aku sudah menghabiskan seluruh tabungan kita." "Kau apa?" ujar Yayoi dengan suara serak. Mereka berdua sudah berhasil menabung lima juta yen lebihhampir cukup untuk uang muka sebuah kondominium. Untuk apalagi dia bekerja membanting tulang di pabrik? " Kenapa kau tega sekali ? Seluruh gajimu sudah kau pakai untuk dirimu sendiri; kenapa kau menghabiskan tabungan kita juga?"

"Aku tidak bercanda."kata Kenji."Tapi tabungan itu bukan milikmu saja."

"Juga bukan milikmu saja" .(Bebas,hal.71)

(...)手で弥生は $\mathrm{T}$ シャツをめくっ てみた。鳩尾をには青黒い痣がくつ 
きりとついていた。それが健司と自 分の終わりの刻印のように感じられ、 長い息を吐くと襖が開いた。

$$
\text { (アウト : 89) }
$$

(.....)Dia mengangkat kausnya dan melihat memar berwarna biru-hitam tepat di bawah dadanya. Pemandangan itu bagaikan tanda terakhir bahwa hubungan antara dirinya dengan Kenji sudah tamat. (Bebas,hal.72)

弥生は鳩尾を手で押さえ、どうにか 食卓の前に座った。痛みをこらえ、 ゆっくりと呼吸を整える。風呂場か らは、プラスチックの桶を蹴飛ばす 音が聞こえてきた。痛にまで当たっ てるんだわ、と弥生はくすりと笑い、 それから両手に顔を埋めた。怒りよ りも、どうしてこんな男と一緒に暮 らしているのかという惨めさが弥生 を打ちのめしていた。

$$
\text { (アウト：89-90) }
$$

Sambil menekan perutnya, Yayoi berjalan ke meja, lalu duduk. Dia menarik nafas lambat-lambat dengan irama teratur untuk mengurangi rasa sakit. Terdengar suara ember plastik jatuh di dalam kamar mandi. Dia tertawa diamdiam dan menangkupkan tangan ke wajahnya. Sengsara sekali rasanya hidup dengan pria semacam ini.(Bebas,hal.72)

Solusi yang dilakukan Yayoi akibat masalah yang menimpa rumah tangganya adalah membunuh suaminya, Yayoi memiliki kedendamam yang memuncak akibat ulah suaminya. Menurut Sullivan (melalui Feist, 2008 ), kedendaman adalah dinamisme yang mengkristal dalam bentuk niat jahat dan rasa benci, dicirikan seperti hidup diantara musuh. Hal ini bisa dilihat di mana rasa benci terhadap suaminya bagaikan berhadapan dengan musuh yang harus segera dilenyapkan, karena Kenji telah menghajar dan tidak menghargai bahkan menghormatinya. Seperti kutipan berikut ini:

その途端ぶつっと音がして弥生の忍 端の系が切れた。弥生は 自分でも 思いがけない素早さで草のベルトを 腰から外し、健司の首に巻きつけて

$$
\text { いた。（アウト：91） }
$$

Pada saat itu lenyaplah sudah kesabaran Yayoi. Secepat kilat dia melepaskan sabuknya dan melilitkannya ke leher Kenji.

((Bebas, hal.73)

$$
\begin{aligned}
& \text { 「...」もつともと苦しめぼいい。こ } \\
& \text { んな男な絶対に存在してほしくない。 } \\
& \text { (アウト : 91) }
\end{aligned}
$$

(.....)Dia harus lebih menderita, pikir Yayoi. Dia tidak berhak terus hidup seperti ini ! ((Bebas, hal.73)

「まだよ。まだ許さない」弥生さら に続けた。このまま死んでしまえば いい、と思ったのは正確な気持では なかった。健司という男の顔を見た くない、喋べるのを 聞きたくない、 そんな一心だった。（アウト：92）

"Belum", guman Yayoi sambil terus menarik sabuk." Aku masih belum memaafkanmu." Dia sebenarnya bukan menginginkan Kenji mati seperti ini, dia hanya ingin memastikan dia tak pernah harus melihat wajah pria itu lagi, tak pernah harus mendengar suaranya lagi. (Bebas, hal.74)

Ego Yayoi merasa terancam oleh perilaku suami yang berupa impuls-impuls id yang tidak inginkannya, dia melindungi diri akibat ketegangan yang dia alami dari tindakan kasar suaminya dengan melakukan pembunuhan. Persisnya, ego Yayoi memaksa perasaan-perasaan yang mengancam kembali ke alam sadarnya.

\section{c. Pengaruh Permasalahan Hidup Yoshie Terhadap Kepribadiannya}

Yoshie mempunyai masalah hidup dimana dia harus merawat ibu mertuanya yang selalu mengeluh dan memarahinya jika pulang tidak tepat waktu. Selain itu dia harus bekerja malam mencari uang untuk memenuhi finansial keluarganya. Hal ini mengakibatkan kejengkelan, kemarahan pada diri Yoshie sehingga dia ingin membunuh ibu mertuanya. Seperti kutipan di bawah ini:

$$
\text { ヨシエが老人に謝ると、姞 }
$$
は口を歪めた。 


\begin{abstract}
「ふん。どこで何してた んだよ。あたしをほっといてさ。も うじき死ぬところだったよ」 ヨシエの心に怒りが渦巻いて、 激しいしぶきを上げた。どうして皆、 勝手なことばかり言うのだ。私が鋼 鉄でできているロボットだと思って いるのだろうか。気が付いたら、ヨ シエは怒鳴っていた。

「だったら死ぬばいい。死んだら、 このあたしがあんたをバラバラにし て生ゴミで出してやるよ。真っ先に その首を落としてやるよ」。（アウ 卜 : 235)
\end{abstract}

Dia mendengar wanita tua itu mendengus, lalu berkata," dari mana saja kau? Kukira kau sudah membiarkanku mati saja di sini."

Yoshie tiba-tiba mengamuk. Kenapa mereka begitu egois?memangnya mereka kira aku ini robot? "silahkan kalau mau!" dia membentak mertuanya.'Dan setelah kau mati, kau akan kupotong-potong dan kubuang dengan sampah! Kepalamu yang jelek dan ubanmu itu duluan!" (Bebas, hal. 185)

「師匠だって、お姑さんを殺したい と思ったこと何度もあるでしょう?」 雅子はすべてを知っていると言わん んばかりに、ヨシエの強張った顔を みつめた。（アウト：121）

" Sudah berapa kali kau merasa ingin membunuh ibu mertuanmu?" Masako melihat wajah Yoshie menegang.

(Bebas, hal. 96)

Solusi yang dilakukan Yoshie akibat kondisi rumah tangga dengan ekonomi minim ditambah dengan tanggungan anak pertama yang menitipkan cucu padanya, serta kebutuhan sekolah anak keduanya. Yoshie ingin menghilangkan segala beban dan ketegangan yang dialami dengan cara berniat membantu Masako memutilasi mayat kenji dan membuangnya, padahal sebenarnya hati nuraniya tidak menghendakinya. Superego Yoshie yang bekerja berdasarkan pertimbangan moral menekan ego agar tidak ikut terlibat, tapi ego Yoshie lebih kuat dari superegonya, sehingga Yoshie akhirnya mau membantu karena dia mempunyai hutang kepada Masako. Seperti kutipan di bawah ini. 「何でそこまでしてやるのよ。あた しは嫌だよ、そんな殺したいと思っ たこと何度もあるでしょう」（アウ 卜 : 120)

"Tapi kenapa? Dan aku harus membantu juga? Aku jadi merinding mendengar ini semua---kita akan jadi kaki tangan pembunuhan." (Bebas, hal.96)

ヨシエは頑固に首を横に振った。

「あたしは駄目。できないよ、そん なこと。絶対」（アウト：120）

"Lupakan saja", kata Yoshie sambil mnggeleng dengan keras kepala."Aku tak sanggup. Yang itu aku tak sanggup." (Bebas, hal.97)

「じや、金返してよ」雅子はテーブ ル越しに手をだした。

(...)“Kalau begitu, kembalikan uang yang kupinjamkan padamu kemarin malam. Sekarang."(Bebas, hal.97)

「金を返すことはできないよ。だか ら、協力するしかないね」

(アウト：122)

"Baiklah kalau begitu," kata Yoshie akhirnya, seperti sudah mengambil keputusan."Aku tak bisa mengembalikan uangmu, jadi rasanya aku harus membantu.'(Bebas, hal.97)

Menurut Freud (melalui Feist, 2008: 28), Superego mengawasi ego dari dekat, menilai tindakan-tindakan dan niat-niatnya. Rasa bersalah (superego) adalah hasilnya ketika ego melakukan tindakan-atau bahkan baru berniat. Sedangkan perasaan rendah diri muncul ketika ego tidak mampu memenuhi standar kesempurnaan superego. Hal ini berarti rasa bersalah adalah fungsi dari suara hati nurani. Hati nurani Yoshie sebenarnya tidak menginginkannya, egonya mendesaknya untuk ikut terlibat. Rasa bersalah (superego) Yoshie terlihat saat dia kalah dari dorongan egonya untuk menyanggupi membantu niat Masako memutilasi mayat Kenji. 


\subsection{Pengaruh Permasalahan Hidup Kuniko Terhadap Kepribadiannya}

Kuniko memiliki wajah tidak cantik dan memiliki tubuh yang gemuk. Untuk menutupi kekurangan itu Kuniko selalu hidup dalam kemewahan dengan hutang kepada rentenir. Apa pun yang dia kenakan untuk menutupi kekurangan itu dia membeli baju, tas, dan aksesoris yang bermerk. Tetapi semua itu selalu terkesan tidak cocok . Seperti kutipan di bawah ini.

「すみません。遅くなって」
邦子は雅子のぼけた赤色のカロー
ラの横に、ゴルフを無造作に停めた。
右に大きく曲がっているが気にする
様子もない。サイブレーキを引く音
も、ドアを閉める音も不必要に強く、
万事派手でけたたましかった。雅子
は煙草をスニーカーの先で揉み消し
た。(アウト: 9)
“Maaf terlambat, ” katanya sambil
memarkir mobil di sebelah mobil Corolla Masako yang warna merahnya sudah memudar. Setirannya asal-asalan, dan dia memasang rem tangan dan menutup pintu dengan suara agak keras. Segala sesuatu yang berhubungan dengannya terkesan cempreng dan norak. (Bebas, hal. 8)

Apa yang dilalakukan Kuniko dalam psikoanalisis Freud merupakan proses primer dalam id, dimana Kuniko membayangkan atau mengkhayalkan sesuatu yang dapat mengurangi atau menghilangkan ketegangan akibat masalah yang melanda hidupnya. Hal tersebut sangat tidak logis karena ia membayangkan mempunyai wajah cantik dan mempunyai tubuh yang indah padahal sebenarnya tidak.

Hal ini berarti id Kuniko menutupi segala kekurangan yang ada padanya dirinya untuk mengurangi ketegangan dalam batinnya dengan cara hidup bermewahmewahan. Akibatnya dia dikejar rentenir. Seperti kutipan di bawah ini.

街の金融業者、通称街金からだ った。自動車ローンのほかに、クレ ジットカードのローンが大きく膨ら んで、邦子は数年、その支払いに追 われている。元金は減らず、利子だ けを払っている状態だということに
気付いたのは去年のことだ。それも 滞ると、サラ金から借りまくって何 とか利子分だけは返したが、今度が サリ金もからも、このままではブラ ックリストに載ると劦されるように なった。（アウト：150)

Telepon itu dari rentenir. Kuniko sudah bertahun-tahun diburu kreditur setelah meminjam uang banyak untuk membeli mobildan melunasi tagihan-tagihan kartu kredit. Tahun lalu dia menyadari bahwa dia sudah tak sempat lagi memikirkan jumlah pokok pinjaman; pembayaran hanya cukup untuk menutupi bunga pinjaman, dan untuk itu pun dia harus bersusah payah. Akhirnya membayar bunga pun makin lama makin sulit, dan dia memulai meminjam uang dari rentenir untuk dibayar kembali dengan gajinya . Sekarang para rentenir itu mengejarnya dan dia tak bisa ke mana-mana lagi. Utangnya sudah berlipat ganda dengan cepat sekali, dan sekarang kreditur biasa maupun rentenir mulai mengancam akan namanya ke dalam daftar hitam mereka. (Bebas, hal: 118)

\section{F.SIMPULAN}

Dari hasil penelitian struktur kepribadian ke empat tokoh utama baik Masako, Yayoi, Yoshie, dan Kuniko lebih banyak dikuasai oleh impuls idnya daripada impuls ego maupun superegonya. Hal ini dikarenakan ciri kerja id ini adalah prinsip kenikmatan ( Pleasure Principle) untuk mereduksi ketegangan /masalah.

Adapun dampak permasalahan hidup terhadap kepribadian empat tokoh utama tersebut adalah Masako memiliki masalah tidak pernah dihargai ditempat kerjanya,Komunikasi yang sulit dengan suami\& rumah tangga yang tidak harmonis serta hubungan yang tidak baik dengan anaknya. Hal ini mengakibatkan ia melakukan tindakan keji untuk mereduksi ketegangan dalam permasalahan hidupnya dengan membantu sahabatnya bernama Yayoi dengan membuang mayat suami Yayoi yang telah dimutilasi. Yayoi memiliki masalah dengan suami yang tidak pernah 
menghargainya \& rumah tangga yang tidak harmonis. Solusi yang dilakukan Yayoi akibat masalah dengan suami dan rumah tangganya adalah ia melakukan tidakan keji dengan membunuh suaminya.

Yoshie mempunyai masalah hidup dimana dia harus merawat ibu mertuanya yang selalu mengeluh dan memarahinya jika pulang tidak tepat waktu. Selain itu dia harus bekerja malam mencari uang untuk memenuhi finansial keluarganya. Hal ini mengakibatkan kejengkelan, kemarahan pada diri Yoshie sehingga dia ingin membunuh ibu mertuanya. Yoshie ingin menghilangkan segala beban dan ketegangan yang dialami dengan cara berniat membantu Masako membuang mayat kenji (suami Yayoi). Kuniko, memiliki masalah bahwa ia tidak memiliki kecantikan wajah dan bentuk tubuh yang sempurna sehingga ia melakukan Tindakan untuk menutupi kekurangan itu dengan selalu hidup dalam kemewahan dengan hutang kepada rentenir, hal ini ia lakukan untuk mereduksi ketegangan dalam hidupnya.

Permasalahan hidup empat tokoh utama di atas akibat mereka tidak dapat menemukan solusi pemecahan dari masalahnya, mereka tidak saling terbuka tentang masalahnya dan lebih senang menyimpannya dalam hati. Padahal hal tersebut berdampak buruk terhadap kepribadiannya, dimana beban masalah yang tidak dapat dipikulnya mengakibatkan empat tokoh utama tersebut melakukan tindakan keji. Masalah lain dari empat tokoh utama tersebut adalah tidak adanya saling pengertian satu dengan lainnya dalam keluarganya dan kurangnya komunikasi.

\section{DAFTAR PUSTAKA}

Darma, Budi. 1983. Solilokui, Kumpulan Esai Sastra. Jakarta: Gramedia.

Endraswara, Suwardi. 2008. Metode Penelitian Psikologi Sastra. Yogyakarta: MedPress.

Feist, Jess, dan Gregory J. Feist. 2008. Theories of Personality. Yogyakarta: Pustaka Pelajar.

Fudyartanta. 2006. Psikologi Kepribadian Freudianisme. Yogyakarta: Zenith Publisher.

Kirino, Natsuo. 2007. Auto. Tokyo: Kodansha. 2007. Bebas (diterjemahkan Lulu Wijaya ). Jakarta: Gramedia Pustaka Utama.

Nurgiyantoro, Burhan. 2005. Teori Pengkajian Fiksi. Yogyakarta: Gadjah Mada University Press.

Ratna, Nyoman Kutha. 2004. Teori, Metode, dan Teknik Penelitian Sastra. Yogyakarta: Pustaka Pelajar.

Semiun, Yustinus. 2006. Teori Kepribadian Terapi Psikoanalitik Freud. Yogyakarta:

Kanisius.

Siswantoro. 2005. Metode Penelitian Sastra: Analisis Psikologis. Surakarta: Muhammadiyah University Press.

Stanton, Robert. 2007. Teori Fiksi Robert Stanton. Yogyakarta: Pustaka Pelajar.

Supardan, Dadang. 2008. Pengantar Ilmu Sosial. Jakarta: PT Bumi Aksara.

Suroso,dkk. 2009. Kritik Sastra: Teori, Metodologi, dan Aplikasi. Yogyakarta: Elmatera Publishing.

Wellek, Rene, and Austin Warren. 1949.

Theory of Literature. New York: Hancourt, Brace and Company 